\section{0. 人工心䁍用人工胸壁の開発}

東大 医用電子研

$\begin{array}{ll}\text { 井街宏 } & \text { 藤正璇 } \\ \text { 三宅 仁 } & \text { 滝戸直人 } \\ \text { 中島正治 } & \text { 河野明正 } \\ \text { 小野俊哉 } & \text { 渥美和彦 }\end{array}$

胸壁上にポンプを置くタイプの完全人工心臟や補助 心臟では，太いカニューレを肋間を通して胸壁上に出 さ权ばならないため, 完全閉胸状態を得るためには肋 間を埋めるための人工胸壁が必要になる。人工心臓用 人工胸壁に要求される条件としては，(1)完全閉胸状態 が得られること，(2)肋骨に良く固定され，運動により 外れないこと，(3)生体組織との療合が良く感染を招か ないこと，(4)胸腔内側で注肺の㾏着を起さないことな どが考えられる.

これらの条件を満足するものとして以下のような人 工胸壁を作成し，ヤギを用いた動物実験を行った．人 工心臟の装着に際してはヤギの左第 4 肋骨を切除する ため，第 3 および第 5 助骨の間にはまるよう形状を設 定すると共に，肋骨との間の密閉状態を保ち，かつ肋 骨への固定を強固にするため両側に溝が設けられた。 4 本のカニューレは人工胸壁に設けられた内径 $25 \mathrm{~mm}$ の 4 本のスリーブを通して体外へ導かれる. 人工胸壁 はP V Cペーストを基材としてキャスティング法とデ イッピング法を組合わせて成型した。体壁側は組織と の憈合を良くするためにテトロンベルーアで覆い，胸 壁側は Avcothane をコーティングした平滑面とテト ロンベルーア被覆面の 2 種類について検討を行った. 試作した人工胸壁は15例の完全人工心臟の実験に用い られた。 その使用期間は 174 日であり，7例で 3 カ月 以上植込まれた。 これらの結果では, ベルーア面は組 織と良く療合し, 肉眼的汇演感染, 炎症などは見られ なかった，胸腔側では，平滑面を用いた場合，平滑面 上に厚い結合組織が形成され，結合組織と平滑面の間 隙に感染巣が生じる様子が観察された. 胸腔側にベル 一アを用いた場合は薄い偽内膜状の組織が形成され， 感染も見られず肺との療着も比較的軽度であった。

以上, 今回開発された人工心臟用人工胸壁は, 完全 閉胸, カニューレの固定, 感染防止などの点で人工心 贜の研究に極めて有用である。
医器学 Vol. 50, No. 4 (1980) (41)

\section{Seamless bladder type assisf heart 及び seamless sac type TAF の作製 方法について}

\author{
広島大 第 1 外科 \\ 同 人工心臟実験施設 \\ 岩宮博川上恭司 \\ 中垣 満 田口一美
}

I bladder type $の$ pump hragm type の pump に比べて pump 内の滞流が 少なく，血栓ができにくいといら特質をもっている. しかしこれまで使用してきた bladder type の pump は, diaphragm と outer shell とを, 別々に作製し ていたため,これらの接合部に, 血栓を生じることが 多功た。我々はこれを解決し, bladder type の pumpの長所を生かすために, 新しい作製法を考案し た。この新作製法では, diaphragm と outer shellを 含めて pump の全体を一体に作製することができ， これによって seamless 構造を得られる. また材質と して Avcothane を採用することによって, 血栓形成 や耐久性, 心拍出量などの面で改善される.この新作 製法によって seamless 構造を有した bladder type の assist heart を試作した.

II TAH の pump 桜機能的にはもちろん形態的 にも自然心に類似していることが望まれる。より自然 心近い人工臓を求めて, 新しい sac type の pu$\mathrm{mp}$ 作製法を考案した. $150 \mathrm{~kg}$ 仔牛の心室を casting し，これを型として Avcothane dipping 法によって diaphragm, housing を含む全体を一体に作製した。

\section{2. マイクロ波による人エ心䁍心室の運動 計測装置の開発}

\begin{tabular}{|c|c|}
\hline 東大 医用電子研 & 藤 \\
\hline 井街 宏 & 三宅 \\
\hline 中島正治 & 河野明 \\
\hline 小野俊哉 & 渥 美 \\
\hline 気通信大学 & \\
\hline$t$ & \\
\hline
\end{tabular}

人工心臟血液ポンプの人工心室の運動は, 心拍出 量, 圧力上昇勾配, 抎張期の過陰圧に関倸がある。 こ の運動の計測法には, 容積式, 光電式などが考えられ てきたが, 心室壁の位置, 移動速度などを安量的汇計 
測しうるものはなかった。

本研究では人工心室壁の絶対位置の計測が非接触で 可能なマイクロ波を用いた距離の測定法により，人工 心室壁の運動状態を観測する方法を開発することを目 標とする。

計測の基本原理は，マイクロ波の送信波㐨よび壁よ りの反射波の位相を検出し, 反射波の位相の遅れを $\omega$ rad とすると壁までの距離 Dは

$$
\mathrm{D}={ }_{4 \pi}^{\omega} \cdot \lambda \quad \text { (但し, } \lambda \text { に用いたマイクロ波の波 }
$$
長)

となることを利用し，壁の移動による $\Delta \mathrm{D}$ を計測する ことにある。

実際の人工心臟ポンプへの応用では次のような仕様 が必要となる.

1）壁の移動量は最大 $1.5 \mathrm{~cm}$ ，移動速度は $10 \mathrm{~cm} / \mathrm{secで}$ あるので，応答時間は $1.5 \mathrm{~m} \mathrm{sec}$ 程度以下が必要であ る.

実際に作製された装置は上記の条件を満 足するよ う, 次のような設計, 構成を行ない, 人工心臓外箱の 外部に取付け使用した。

探触子部は送信部として $10,525 \mathrm{GHz}$. 出力 $10 \mathrm{~mW}$ の ガンダイオード発振器と, 受信部として $\frac{1}{4}$ 波長離れた 2 個のダイオード検波器よりなり，その大きさは $4 \times$ $4 \times 4.5 \mathrm{~cm}$, 重量約 $100 \mathrm{~g}$ である. 信号処理部は20×30 $\times 25 \mathrm{~cm}$ の大きさで重量約 $1.2 \mathrm{~kg}$ ，電源として $15 \mathrm{~V} 100$ $\mathrm{m} \mathrm{A}, 8 \mathrm{~V} 200 \mathrm{~m} \mathrm{~A}, 5 \mathrm{~V} 500 \mathrm{~m} \mathrm{~A}$ の直流を要する.

模擬循環装置に取付けた人工心臟血液ポンプに本装 置を取付け，心室壁の運動を観測したところ，心拍数 $100 \mathrm{bpm}$ に対し，十分な $\mathrm{S} / \mathrm{N}$ 比，空間分解能，応答時 間を持ち，心室壁の局所的な変形および移動速度の計 測が定量的に行え，その結果心拍出量，人工心室の機 械的な歪, 圧力の立上り速度などが解析可能となっ た.

\section{3. 大動脈一大動脈バイパス法による} 人工心䁍ポンプ性能に関する研究

広島大 第 1 外科

同人工心臟実験施設

$\begin{array}{lll}\text { 中垣 } & \text { 満 } & \text { 川上恭司 } \\ \text { 岩宮 } & \text { 博 } & \text { 田上重喜 } \\ \text { 松村 } & \text { 誠 } & \text { 田口一美 }\end{array}$

目的：人工心臓ポンプ内の血栓形成性とその血栓形 成による全身臟器, 特に腎臓への影響および左房一大 動脈, 左室一大動脈バイパス形式による補助心臓にお けるポンプ離脱時, 一時停止した場合のポンプ内の抗
血栓性機能の判定について, 無抬動下人工心臓ポンプ による大動脈一大動脈バイパスを行ない検討を加え た.

実験方法：体重 95〜150kgの仔牛を用いて，全身麻 酔下に左側開胸を行ない，胸部大動脈にクイックコネ クター付人工血管を 2 カ所で端側吻合し，これらに人 工心臟ポンプを接続した.この間の大動脈は完全に癄 断して，血液は完全にポンプ内をバイパスするように した. ダイアフラム型アブコセン製ポンプで, 最大 1 回拍出量は $100 \mathrm{~m} l$, その流入出口には Björk-Shiley 人工弁を持っている. ポンプ内ダイアフラムは拡張期 相に固定してある。術後は固定ケージに移し，経過観 察を行なった。原則として術後の抗凝固療法は行なわ なかった。

結果：1）3頭の仔牛に本法を施行し，1 例は術後 4

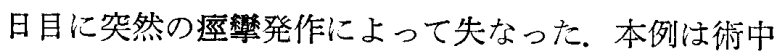
のへパリン投与のみで術後はまったく抗凝固療法を行 なわず，剖検所見としてポンプ内の人工弁周囲，フィ ックコネクター接続㓮周囲に血栓形成を認め, 血流は わずかに保たれていた状態であった．また大動脈遮断 が不完全であった．腎臟は灰白色を呈し虚血状態にあ った. 2)他の 2 例では術後クーファリンを投与, プロ トロンビン時間をコントロール値の150～200\%に維持 して, 術後 3 週間現在, 外観上はまったく正常な発育 をつつけけいる．3)術後 1 力月経過後, 剖検を行ない 前述の目的について検討を加える予定である，4)本法 は本移植実験に先立って，ポンプの機能をより簡単な 方法で行なえる.

\section{4. 左房一大動脈バイパス法の碋究}

広島大 第 1 外科

同人工心臟実験施設

川上恭司岩宮博

田上重喜松村誠 大坪厚美広中智之 中垣 満 田口一美

目的及び方法 補助心臟は重症な心臓の Pump 機 能不全に対し，その重症度に応じて長期間の補助が目 的とされているが，左房一大動脈 Bypass 法において は，低圧系の左房よりの脱血はしばしば困難であり， また長期補助における血栓形成の問題も無視できな い. そこで重症度に応じて, 左房への過㓌圧をかける ことなく, 左房への還流量すなわち左房圧に応じて smooth に拍出量が得られる副室付補助心臓 Pump を 開発, mock circulation 装置を用いてその性能 試 験 